\title{
EFEKTIVITAS KETERLIBATAN PENYUSUNAN KEY PERFORMANCE INDICATOR DALAM MENURUNKAN TINGKAT RESISTENSI TERHADAP PERUBAHAN SASARAN KINERJA
}

\author{
EFFECTIVENESS OF INVOLVEMENT IN ARRANGING KEY PERFORMANCE \\ INDICATOR TO DECREASE OF RESISTANCE TO CHANGE LEVEL TOWARDS \\ PERFORMANCE TARGET
}

\author{
Nina Fitriana \\ Alimatus Sahrah \\ Reny Yuniasanti \\ Program Studi Psikologi Profesi, Universitas Mercu Buana, Yogyakarta \\ Email: niafitrianafelani@gmail.com
}

\begin{abstract}
This research aims to examine the effectiveness of involvement in arranging key performance indicator to decrease of resistance to change level towards performance target for management trainee in University $X$. The subject of this research is management trainee consisting of experiment group and control group. The experiment group comprised of 16 people while the control group consisted of 8 people. The subjects of this research have at least master degree, work contract, and medium to high level of resistance to change for target performance. The research design used pretest posttest control group design. The data collection is conducted using scale of resistance to change for taget performance. The finding of this research indicated that the involvement in arranging key performance indicator is effective in decreasing the resistance to change level towards performance target for management trainee in University $X$.
\end{abstract}

Key words: resistance to change, involvement, key performance indicator

\begin{abstract}
ABSTRAK
Penelitian ini bertujuan untuk menguji efektivitas keterlibatan penyusunan Key Performance Indicator dalam menurunkan tingkat resistensi terhadap perubahan sasaran kinerja management trainee Universitas X. Subjek dalam penelitian ini adalah management trainee yang dibagi ke dalam dua kelompok, yaitu kelompok eksperimen dan kelompok kontrol. Kelompok eksperimen terdiri atas 16 orang dan kelompok kontrol terdiri atas 8 orang. Karakteristik subjek dalam penelitian ini adalah memiliki latar belakang pendidikan minimal S2, terikat perjanjian kerja, dan memiliki tingkat resistensi terhadap perubahan sasaran kinerja yang sedang dan tinggi. Desain penelitian ini menggunakan pretest posttest control design. Pengumpulan data dalam penelitian ini adalah dengan menggunakan skala resistensi terhadap perubahan sasaran kinerja. Hasil penelitian menunjukkan bahwa keterlibatan penyusunan Key Performance Indicator terbukti efektif dalam menurunkan tingkat resistensi terhadap perubahan sasaran kinerja pada management trainee Universitas X.
\end{abstract}

Kata kunci: resistensi terhadap perubahan, keterlibatan, indikator kinerja utama 
Perubahan merupakan fenomena yang dihadapi oleh individu maupun organisasi (Foster, 2008). Persaingan global, perkembangan teknologi, dan perubahan dinamis lainnya memicu perubahan pada organisasi. Menghadapi perubahan tersebut, organisasi harus lebih bersifat kompetitif dan fleksibel. Dengan demikian, melakukan sebuah perubahan merupakan suatu keharusan bagi sebuah organisasi. Salah satu hal yang dilakukan oleh organisasi dalam menghadapi perubahan adalah dengan mengkaji ulang kebijakan termasuk di dalamnya terkait dengan sistem penilaian kinerja (Foster, 2008).

Perguruan tinggi sebagai salah satu bentuk organisasi yang bergerak di bidang pendidikan juga harus senantiasa melakukan perubahan (Oebaidillah, 2017). Terkait dengan hal tersebut, Suyatno (Oebaidillah, 2017) menyatakan bahwa menghadapi era Masyarakat Ekonomi ASEAN (MEA) dan era global, kalangan perguruan tinggi harus terbuka dan mau berubah. Selain itu, perubahan merupakan keniscayaan. Jika kalangan perguruan tinggi tidak mau berubah, maka perguruan tinggi tersebut akan ketinggalan. Perguruan tinggi harus terbuka dengan perubahan untuk siap berkompetisi. Agar siap menghadapi perubahan, Suyatno (Oebaidillah, 2017) juga menyatakan bahwa perguruan tinggi harus kreatif dan melakukan inovasi, misalnya dalam melakukan riset serta meningkatkan kualitas dosen. Setelah berino- vasi, perguruan tinggi juga harus meningkatkan indeks daya saing agar maju dengan bersinergi dan kolaborasi bersama perguruan tinggi lainnya. Perguruan tinggi juga harus melaksanakan Tri Dharma Perguruan Tinggi dengan baik yang meliputi pendidikan, penelitian atau riset, dan pengabdian masyarakat. Terutama dalam hal riset dan jurnal ilmiah, dosen harus lebih produktif menerbitkan publikasi ilmiah nasional dan internasional agar tidak kalah dengan dosen di negara Asean lainnya.

Selain itu, Sailah (Oebaidillah, 2017 ) juga menyatakan bahwa perguruan tinggi dan dosen harus produktif dan membudayakan riset dan publikasi ilmiah. Para dosen harus produktif menulis karya dan publikasi ilmiah nasional maupun internasional. Hal ini penting guna meningkatkan daya saing. Berdasarkan penjelasan tersebut, dapat dikatakan bahwa perubahan merupakan hal yang penting untuk dilakukan oleh perguruan tinggi.

Terdapat beberapa alasan yang menuntut Universitas $X$ untuk melakukan perubahan. Pertama, rebranding Universitas $\mathrm{X}$ menuntut perubahan lain yang harus dilakukan. Rebranding Universitas X yang telah dilakukan menjadi university of petroleum memberikan konsekuensi pada perubahan tujuan organisasi dan sasaran kinerja. Kedua, persaingan yang ketat antar Universitas swasta yang berada di 
Yogyakarta juga menuntut Universitas $\mathrm{X}$ untuk melakukan perubahan.

Perubahan organsiasi perlu didukung oleh perubahan pada karyawan. Hal ini sejalan dengan pendapat Cotter dan Cohen (2002) bahwa usaha perubahan dalam organisasi yang paling sukses itu tidak hanya terkait dengan strategi dan sistem, namun terkait erat dengan perubahan perilaku orang per orang, sehingga dapat dikatakan bahwa keinginan dan kerelaan untuk berubah yang berasal dari individu sangatlah penting.

Management trainee sebagai salah satu bagian penting pada Universitas $X$ perlu mendukung perubahan yang akan dilakukan organsiasi. Management trainee ini terdiri atas para calon dosen muda yang diarahkan selain mampu melakukan tri dharma perguruan tinggi juga melakukan tugas manajemen organisasi. Universitas $X$ memiliki 42 management trainee. Harapannya management trainee menganggapi positif sebuah perubahan.

Selain itu, mereka juga mampu menerima dan mencapai sasaran kinerja yang berubah sebagai konsekuensi dari perubahan organsiasi. Misalnya, sebelum rebranding mereka diwajibkan melakukan publikasi dalam tema umum atau sesuai dengan latar belakang pendidikannya, namun setelah rebranding diberlakukan, mereka harus menulis artikel dan melakukan publikasi dengan tema khusus, yaitu migas dan energi. Selain itu, harapannya mereka mampu melakukan sesuatu di luar rutinitas sehari-hari. Management trainee dituntut untuk tidak hanya mengajar namun melakukan penelitian dan publikasi serta pengabdian masyarakat.

Selain itu, penolakan dalam perubahan dapat terjadi dalam berbagai bentuk, timbulnya diharapkan menyukai perubahan dan mampu menerima perubahan dengan cara menyadari terlebih dahulu bahwa perubahan yang terjadi pada organsiasi salah satunya terkait dengan perubahan target atau sasaran kinerja. Management trainee juga diharapkan mampu bersikap open mind dengan berfikir bahwa perubahan akan membawa dampak positif bagi dirinya (Palmer, Dunforn, \& Akin, 2006)

Perubahan-perubahan yang dilakukan oleh organisasi yang harapannya dapat diterima oleh anggota organisasi tidak selalu diterima oleh anggota organsiasi (Kreitner \& Kinicki, 2001). Penolakan terhadap perubahan dapat terjadi dalam berbagai bentuk, di antaranya adalah hilangnya kesetiaan, hilangnya motivasi kerja, timbulnya banyak kesalahan, bekerja lambat, dan banyak absensi. Perilaku enggan untuk berubah ini dinamakan resistensi terhadap perubahan. Resistensi terhadap perubahan adalah suatu respon emosional atau perilaku terhadap ancaman nyata atau imajinasi 
yang terjadi pada rutinitas kerja yang sudah mapan (Oreg, 2003).

Perilaku resistensi terhadap perubahan yang muncul di Universitas $X$ di antaranya adalah management trainee tidak menganggap positif perubahan. Management trainee hanya melakukan rutinitas sehari-hari seperti mengajar. Management trainee menghindari untuk melakukan publikasi dan penelitian maupun pengabdian masyarakat. Beberapa lainnya bekerja melebihi deadline dengan alasan bahwa waktu mereka habis untuk mengerjakan tugas yang lain. Satu dari management trainee lainnya menyatakan bahwa melakukan publikasi berita dan artikel bukanlah merupakan tugas dari management trainee sehingga ia tidak berusaha untuk mengerjakannya.

Permasalahan lain adalah para management trainee tidak senang dengan perubahan yang terjadi. Hal ini dibuktikan dengan hasil wawancara awal pada tanggal 13 April 2017 pada tiga management trainee yang menyatakan bahwa management trainee merasa tidak nyaman dengan perubahan sasaran kinerja yang diberlakukan. Sebagai bentuk ketidaksenangan, beberapa management trainee memilih untuk tidak melaksanakan job description mereka bahkan memilih untuk mengundurkan diri. Hal ini dibuktikan dengan tingginya tingkat turn over. Hasil wawancara menyatakan bahwa dari $100 \%$ proses rekrutmen dan seleksi, management trainee yang mampu bertahan adalah hanya sebesar $20 \%$ saja. Berdasarkan hasil wawancara, salah satu management trainee pernah berfikir untuk mengundurkan diri dari Universitas $\mathrm{X}$.

Selain itu, beberapa management trainee tidak mampu menerima perubahan yang diberlakukan. Hal ini dibuktikan dengan hasil wawancara yang menyatakan bahwa mereka menganggap bahwa perubahan akan merepotkan sehingga mereka cenderung untuk menghindarinya. Salah satu job description yang muncul sebagai konsekuensi dari rebranding adalah bahwa management trainee harus melakukan tugas manajerial. Tugas manajerial ini yang dihindari dan dianggap berat oleh management trainee. Berdasarkan hasil wawancara, management trainee menyatakan bahwa tugas manajerial merupakan tugas yang berat, karena memakan banyak waktu.

Permasalahan berikutnya adalah management trainee berfikir bahwa mereka tidak memperoleh keuntungan dari perubahan yang terjadi. Hal ini dibuktikan dengan para management trainee sulit menerima masukan terkait dengan perubahan, misalnya ketika atasan mereka mengingatkan batas waktu pengumpulan suatu tulisan atau artikel, para management trainee mengiyakan namun mereka sebenarnya tidak melakukannya. 
Berdasarkan penjelasan di atas, dapat dikatakan bahwa management trainee Universitas $\mathrm{X}$ mengalami permasalahan terkait dengan tingginya tingkat resistensi terhadap perubahan sasaran kinerja. Hal ini mengacu pada pendapat Oreg (2003) bahwa aspek resistensi terhadap perubahan terdiri atas reaksi emosi negatif terhadap perubahan, enggan melakukan suatu perubahan, memiliki fokus jangka pendek ketika bekerja, dan memiliki pemikiran yang kaku (tidak open mind) terhadap perubahan.

Menurut Kotter dan Schlesinger (Yilmaz \& Kilacoglu, 2013), resistensi terhadap perubahan dapat diatasi dengan berbagai cara di antaranya adalah dengan pendidikan dan komunikasi, keterlibatan dan partisipasi, fasilitasi dan dukungan, negosiasi dan persetujuan, manipulasi dan kooptasi, dan paksaan secara implisit dan ekspisit. Keterlibatan menjadi salah satu cara dalam mengatasi resistensi terhadap perubahan.

Terdapat beberapa alasan mengapa peneliti menggunakan keterlibatan penyusunan key performance indicator dalam mengatasi permasalahan resistensi terhadap perubahan pada sasaran kinerja. $\mathrm{KPI}$ berisi tentang sasaran kinerja dan KPI merupakan salah satu bentuk penilaian kinerja berdasar target (Soemohadiwidjojo, 2015). Permasalahan yang muncul pada management trainee adalah munculnya resistensi terhadap perubahan sasaran kinerja. Berdasarkan penjelasan tersebut, KPI dapat menjadi salah satu solusi dalam mengatasi permasalahan terkait dengan resistensi terhadap perubahan pada sasaran kinerja karyawan.

Key Performance Indicator mengedepankan komitmen dan keterlibatan karyawan. Salah satu sesi keterlibatan penyusunan KPI adalah dengan diadakannya performance meeting yang meminta karyawan untuk turut terlibat dalam menentukan target dan bobot kinerja bersama-sama dengan pimpinan (Soemohadiwidjojo, 2015). Hal ini selaras dengan hasil penelitian yang dilakukan oleh Khattak, dkk (2012) bahwa keterlibatan dapat meningkatkan komitmen karyawan. Hal ini sejalan dengan pendapat Cummings dan Worley (2005) bahwa keterlibatan karyawan meningkatkan komitmen karyawan. Hasil penelitian Freddy dan Mbohwa (2013) juga menyatakan bahwa kurangnya keterlibatan karyawan akan berdampak pada resistensi terhadap perubahan. Pendapat ini juga diperkuat dengan hasil penelitian Zulkarnain dan Hadiyani (2014) yang me-nyatakan bahwa komitmen dan keterlibatan karyawan berkontribusi terhadap kesiapan karyawan untuk berubah, sehingga pelibatan management trainee dalam menyusun KPI menjadi penting. Keterlibatan management trainee dalam menyusun KPI diharapan dapat menurunkan tingkat 
resistensi terhadap perubahan pada sasaran kinerja.

Permasalahan resistensi terhadap perubahan sasaran kinerja merupakan permasalahan yang terkait dengan aspek afeksi sehingga melibatkan karyawan dalam menentukan target capaian kinerja menjadi penting. Hal ini sejalan dengan pendapat Shuck dkk (2011) bahwa keterlibatan merupakan proses kognitif individu secara emosional dan perilaku yang diarahkan menuju hasil yang diinginkan oleh organisasi.

Permasalahan terkait dengan aspek afeksi akan lebih efektif diatasi dengan hal yang juga dapat menyasar aspek afeksi. Keterlibatan sangat mengedepankan aspek afeksi. Hal ini sejalan dengan hasil penelitian Palmer (2006) yang menyatakan bahwa aspek emosi penting dalam mengkomunikasikan perubahan. Aspek emosi dapat menjadi alat yang sangat penting untuk memunculkan keinginan, komitmen, dan usaha karyawan untuk melakukan suatu perubahan. Urgensi dapat dikomunikasikan lewat appeal emosional, visi dapat ditanamkan juga melalui appeal emosional, dan dengan appeal emosional perubahan yang hebat juga dapat dilakukan. Membawa karyawan pada emosi positif dapat memberikan ketertarikan pada karyawan terhadap perubahan (Palmer, 2006).

Selain itu, Agocs (1997) mengatakan bahwa individu akan cenderung resisten terhadap perubahan dikarenakan adanya kekhawatiran akan ketidaktahuan informasi. Pelibatan karyawan dalam penyusunan KPI merupakan salah satu cara pemberian informasi tekait dengan sasaran kinerja. Sembiring (2009) menyatakan bahwa resistensi terhadap perubahan dapat diatasi dengan keterlibatan, partisipasi dan negosiasi. Pada kegiatan penyusunan $\mathrm{KPI}$, karyawan dapat dilibatkan secara aktif dengan cara menentukan KPI secara bersama sama dengan pimpinan, berpartisipasi aktif dan melakukan negosiasi.

Berdasarkan paparan di atas, dapat disimpulkan bahwa keterlibatan penyusunan KPI dapat menjadi salah satu solusi dalam mengatasi permasalahan terkait dengan resistensi terhadap perubahan pada sasaran kinerja. Perilaku mau berubah pada management trainee memberikan manfaat pada management trainee untuk mengembangkan diri secara maksimal. Selain itu, Universitas $X$ akan mampu memenuhi target perubahan yang diharapkan.

Penelitian ini dibatasi pada seberapa besar pengaruh keterlibatan penyusunan Key Performance Indicator terhadap penurunan tingkat resistensi terhadap perubahan pada sasaran kinerja management trainee Universitas X. Berdasarkan latar belakang permasalahan di atas, rumusan masalah pada penelitian ini adalah seberapa besar pengaruh keter- 
libatan penyusunaan Key Performance Indicator terhadap penurunan tingkat resistensi terhadap perubahan pada sasaran kinerja management trainee Universitas X.

Penelitian ini bertujuan untuk menguji efektivitas keterlibatan penyusunan Key Performance Indicator dalam menurunkan tingkat resistensi terhadap perubahan sasaran kinerja management trainee Universitas $X$. Penelitian ini memiliki dua kemanfaatan, di antaranya adalah penelitian ini diharapkan dapat menambah informasi dan khasanah keilmuan psikologi khususnya Psikologi Industri dan Organisasi dalam mengatasi permasalahan terkait resistensi terhadap perubahan sasaran kinerja dengan cara melibatkan karyawan dalam penyusunan key performance indicator. Apabila hasil penelitian ini terbukti bahwa keterlibatan penyusunan KPI efektif dalam menurunkan tingkat resistensi terhadap perubahan sasaran kinerja pada management trainee Universitas X, maka KPI dapat direkomendasikan untuk diterapkan guna menurunkan tingkat resistensi terhadap perubahan sasaran kinerja tersebut dengan cara melibatkan karyawan dalam penyusunan $\mathrm{KPI}$.

Terdapat dua hipotesis dalam penelitian ini. Pertama, ada perbedaan skor resistensi terhadap perubahan sasaran kinerja antara management trainee yang terlibat dan yang tidak terlibat dalam penyusunan KPI. Management trainee yang terlibat dalam penyusunan KPI memiliki skor resistensi terhadap perubahan sasaran kinerja yang lebih rendah dibandingkan dengan management trainee yang tidak terlibat dalam penyusunan KPI. Kedua, keterlibatan penyusunan KPI efektif menurunkan tingkat resistensi terhadap perubahan sasaran kinerja pada management trainee Universitas X.

\section{METODE PENELITIAN}

\section{Desain Penelitian}

Penelitian ini menggunakan desain eksperimen randomized pretest-posttest control group design. Kelompok dalam penelitian ini dibagi menjadi dua, yaitu kelompok eksperimen dan kelompok kontrol sebagai pembanding (Latipun, 2006). Kelompok eksperimen adalah kelompok partisipan yang memperoleh tritmen. Tritmen digunakan dengan menggunakan metode ceramah/presentasi, FGD, tanya jawab, dan simulasi.

Kelompok kontrol adalah kelompok partisipan yang diberikan perlakuan berupa keterlibatan penyusunaan KPI yang sama setelah kelompok eksperimen diberi perlakuan atau dengan menggunakan metode waiting list. Hal ini dilakukan dengan tujuan untuk mengetahui perbedaan skor resistensi terhadap perubahan diantara subjek yang diberikan tritmen 
dan subjek yang tidak diberikan tritmen.

Bentuk rancangan pretest posttest control

group design adalah sebagai berikut:

Tabel 1. Rancangan Pretest Posttest Control Group Design

\begin{tabular}{lllll}
\hline \multirow{2}{*}{$\mathrm{N}$} & $\mathrm{KE}$ & $\mathrm{T} 1$ & $\mathrm{X}$ & $\mathrm{T} 2$ \\
\cline { 2 - 5 } & $\mathrm{KK}$ & $\mathrm{T} 1$ & $\mathrm{O}$ & $\mathrm{T} 2$ \\
\hline
\end{tabular}

Keterangan:

$\mathrm{R} \quad$ : Random assignment

KE : Kelompok Eksperimen

KK : Kelompok Kontrol

T1 : Prates

$X \quad$ : Perlakuan

O : Tanpa perlakuan

T2 : Pascates

Desain ini melibatkan dua kelompok subjek, yaitu kelompok eksperimen atau kelompok yang diberikan perlakuan berupa kegiatan keterlibatan penyusunan KPI dan kelompok kontrol yaitu kelompok yang tidak diberikan perlakuan berupa kegiatan keterlibatan penyusunan KPI. Desain ini akan melihat efek dari perlakuan kegiatan keterlibatan penyusunan $\mathrm{KPI}$ untuk menurunkan tingkat resistensi terhadap perubahan sasaran kinerja pada management trainee dengan cara membandingkan skor resistensi terhadap perubahan sasaran kerja antara kelompok eksperimen sebelum dan sesudah diberikan perlakuan kegiatan keterlibatan penyusunan KPI dengan kelompok kontrol yang tidak diberikan perlakuan kegiatan keterlibatan penyusunan KPI.

\section{Subjek Penelitian}

Subjek dalam penelitian ini adalah management trainee di Universitas $\mathrm{X}$. Jumlah subjek dalam penelitian ini adalah 42 orang. Karakteristik subjek adalah berlatar belakang pendidikan minimal S2, terikat perjanjian kerja sebagai management trainee dengan Universitas $X$, dan memiliki skor resistensi terhadap perubahan yang sedang hingga sangat tinggi. Proses dalam menentukan subjek dalam keterlibatan penyusunaan $\mathrm{KPI}$ ini adalah hasil skrining subjek dengan menggunakan skala prates, kemudian mengidentifikasi para management traineee yang memiliki skor yang sedang hingga tinggi. Para management trainee yang memiliki skor yang sedang hingga sangat tinggi merupakan manajement trainee yang 
memenuhi syarat sebagai subjek penelitian.

\section{Metode Pengumpulan Data}

Alat pengumpul data yang digunakan untuk mengukur variabel tingkat resistensi terhadap perubahan sasaran kinerja adalah skala resistensi terhadap perubahan sasaran kinerja yang berpedoman pada indikator resistensi terhadap perubahan menurut Oreg (2003). Skala yang digunakan dalam penelitian merupakan skala hasil modifikasi dari skala resistensi perubahan Oreg (2003). Empat aspek resistensi terhadap perubahan, yaitu fokus pada rutinitas, reaksi emosi, fokus jangka pendek, dan kekakuan kognitif digunakan Oreg (2003) dalam menyusun skala resistensi terhadap perubahan. Modifikasi yang dilakukan oleh peneliti adalah dengan menerjemahkan skala dari Oreg (2003) dan menambahkan aitem pada skala favorable dan unfavorable.

Skala ini bertujuan untuk mengukur kecenderungan individu untuk menolak atau menghindari perubahan, tidak menganggap penting perubahan, tidak menyukai konteks dan jenis perubahan. Skala ini terdiri atas 4 aspek, yaitu fokus pada rutinitas, reaksi emosi, fokus jangka pendek, dan kekakuan kognitif. Fokus pada rutinitas adalah komponen perilaku dari resistensi terhadap perubahan terkait dengan kecenderungan seseorang untuk melakukan sesuatu secara rutin. Reaksi emosi adalah komponen afektif dari resistensi terhadap perubahan terkait dengan sejumlah stress dan kegelisahan yang disebabkan oleh perubahan. Fokus jangka pendek adalah komponen afektif dari resistensi terhadap perubahan terkait dengan sejauh mana individu terganggu oleh ketidaknyamanan jangka pendek yang disebabkan oleh perubahan. Kekakuan kognitif adalah komponen kognitif dari resistensi terhadap perubahan terkait dengan frekuensi dan kemudahan seseorang dalam merubah pikiran mereka.

Bentuk skala yang digunakan dalam penelitian ini adalah skala likert. Menurut Sugiyono (2012), skala likert adalah skala yang digunakan untuk mengukur sikap, pendapat, persepsi seseorang atau sekelompok orang tentang fenomena sosial. Skala dalam ini terdiri atas 29 aitem yang terbagi menjadi aitem favorable dan aitem unfavorable. Subjek diminta untuk menjawab pertanyaan dengan cara memilih satu dari alternatif jawaban yang tersedia. Semakin tinggi skor, berarti subjek memiliki skor resistensi terhadap perubahan sasaran kinerja yang tinggi. Sebaliknya semakin rendah skor maka subjek memiliki skor resistensi terhadap perubahan sasaran kinerja yang rendah. Setelah diujicobakan, hasil analisis menunjukkan skala ini memiliki koefisien alpha 0.877, dan koefisien korelasi aitem-total 0.302 0.608 . 
Alat pengumpulan data yang lain adalah lembar observasi untuk mengukur variabel tingkat keterlibatan karyawan dalam kegiatan penyusunan KPI. Lembar observasi yang disusun oleh peneliti berdasarkan aspek tahapan keterlibatan dalam penyusunan KPI. Berdasarkan aspek keterlibatan dalam penyusunan KPI tersebut, terdapat 4 tahapan keterlibatan penyusunan KPI yaitu keterlibatan dalam menentukan faktor kunci keberhasilan, keterlibatan dalam mengkomunikasikan tujuan KPI ke seluruh jajaran organisasi, keterlibatan dalam memilih dan mengembangkan KPI, dan keterlibatan dalam menetapkan target KPI. Observasi dilakukan kepada management trainee ketika mengikuti kegiatan keterlibatan penyusunan KPI. Observasi ini dilakukan untuk melihat keterlibatan peserta dalam mengikuti kegiatan penyusunan KPI. Data observasi ini digunakan sebagai data pelengkap dalam penelitian.

Masing-masing tahapan digambarkan dalam 4 aspek keterlibatan, yaitu keseriusan, keaktifan, partisipasi dalam membuat keputusan, dan tingkat dukungan peserta terhadap kegiatan. Masingmasing aspek dituangkan dalam bentuk skala semantik diferensial. Semantik diferensial adalah jenis skala yang menggunakan stimulus berupa kata.

Tingkat keseriusan peserta dalam kegiatan keterlibatan terdiri atas 4 level perilaku, yaitu menyepelekan (1), ber- minat (2), sungguh-sunguh (3), dan serius (4). Kedua, yaitu tingkat keaktifan peserta yang dilihat dari 4 tingkatan perilaku yaitu pasif (1), acuh (2), peduli/perhatian (3), dan aktif/ikut serta dalam kegiatan (4). Ketiga, tingkat partisipasi peserta yang dapat dilihat dari 4 tingkatan perilaku yaitu diam (1), berpartisipasi dengan mengungkapkan pertanyaan (2), menyumbangkan ide dengan memberikan komentar (3), dan ikut serta membuat keputusan dengan melakukan diskusi (4). Keempat, tingkat dukungan peserta yang dapat dilihat dari 4 tingkatan perilaku yaitu menolak (1), tertarik (2), menerima (3), dan mendukung (4). Semakin tinggi skor, maka semakin tinggi pula tingkat keterlibatan karyawan dalam kegiatan penyusunan KPI. Lembar observasi tersebut diisi oleh tim observer pada saat peserta mengikuti kegiatan.

\section{Prosedur Intervensi}

Kegiatan keterlibatan penyusunan KPI pada management trainee merupakan bentuk perlakuan dalam penelitian eksperimen. Kegiatan ini terdiri atas 4 sesi besar yang berlangsung selama 8 jam. Kegiatan dimulai dengan pembukaan. Kegiatan dibuka oleh Wakil Rektor I Universitas $\mathrm{X}$ kemudian dilanjutkan dengan perkenalan trainer dengan peserta. Kegiatan selanjutnya adalah pengisian 
inform consent dan prates evaluasi pengetahuan.

Setelah pembukaan, maka dilanjutkan dengan sesi 1 , yaitu keterlibatan dalam menentukan faktor-faktor kunci keberhasilan. Pada sesi ini peserta menentukan secara bersama-sama serta menyepakati Faktor Kunci Keberhasilan (FKK) yang dilakukan melalaui proses pengumpulan data dari pemangku kepentingan. Data yang berhasil dikumpulkan pada saat proses analisis pemangku kepentingan, analisis internal eksternal, serta identifikasi isu strategis digunakan sebagai bahan untuk mengidentifikasi faktor kunci keberhasilan. Selanjutnya, dari data yang berhasil dikumpulkan, pihak pimpinan dalam hal ini Wakil Rektor I dapat melakukan diskusi untuk mengidentifikasi faktor kunci keberhasilan yang akan banyak membantu dalam merumuskan KPI. Sesi 2 yaitu keterlibatan peserta dalam mengkomunikasikan tujuan dari KPI ke seluruh jajaran organisasi. Pada tahap ini atasan menjelaskan alasan dan tujuan penerapan KPI secara terbuka yang melibatkan semua pihak terkait. Sesi ketiga, keterlibatan dalam memilih faktor kunci keberhasilan dengan saling menyepakati 5 hingga 8 poin yang dipilih untuk KPI. Sesi keempat, keterlibatan dalam menetapkan target KPI dengan menyepakati target atau sasaran kinerja yang akan diberlakukan, keterlibatan dalam menentukan indikator untuk setiap target kinerja, keterlibatan dalam menentukan target untuk setiap indikator, keterlibatan dalam melakukan pembobot-an KPI, dan keterlibatan dalam melakukan penghitungan skor KPI. Kegiatan selanjutnya adalah penutupan dengan melakukan debriefing. Selanjutnya peserta diminta untuk mengisi lembar evaluasi reaksi dan evaluasi pengetahuan.

\section{Metode Analisis Data}

Analisis yang digunakan adalah dengan menggunakan t-test untuk menguji perbedaan tingkat resistensi terhadap perubahan antara kelompok eksperimen dan kelompok kontrol sebelum dan sesudah dilakukan perlakuan. Data yang dianalisis terdiri atas skor prates dan skor pascates pada subjek dalam kelompok eksperimen.

\section{HASIL PENELITIAN}

Uji hipotesis dilakukan untuk melihat apakah terdapat penurunan tingkat resistensi terhadap perubahan sasaran kinerja pada kelompok eksperimen yang mengikuti kegiatan keterlibatan penyusunan KPI dibandingkan dengan kelompok kontrol yang tidak terlibat dalam penyusunan $\mathrm{KPI}$. Independent $t$ test digunakan untuk melakukan uji hipotesis tersebut. Selain menggunakan independent $t$ tes, peneliti juga menggunakan paired $t$ test. 
Uji dengan independent t-test dilakukan untuk melihat perbedaan skor prates kelompok eksperimen dan kontrol, perbedaan gain score kelompok eksperimen dan kelompok kontrol, serta perbedaan skor pascates kelompok eksperimen dan kelompok kontrol.

Pengujian hipotesis dalam penelitian ini menggunakan uji t. Analisis ini digunakan untuk mengetahui perbedaan skor prates dan pascates sehingga dapat dilihat pengaruh keterlibatan penyusunan KPI terhadap penurunan resistensi terhadap perubahan sasaran kinerja. Uji beda gain score kelompok eksperimen dan kelompok kontrol digambarkan dalam tabel berikut:

Tabel 2. Hasil Analisis Uji Beda Kelompok Eksperimen dan Kontrol

\begin{tabular}{lllllll}
\hline Kelompok & Mean & SD & $\begin{array}{l}\text { Selisih } \\
\text { rata-rata } \\
\text { skor }\end{array}$ & Koef & Signifikansi (p) & Kesimpulan \\
\cline { 1 - 5 } Eksperimen & $-5,125$ & 6,11 & 5,5 & $-2,320$ & 0,003 & Signifikan \\
\cline { 1 - 3 } & 0,3750 & 3,73 & & & 03 \\
\hline
\end{tabular}

Berdasarkan hasil analisis dapat dilihat bahwa analisis statistik uji-t terhadap data prates KK dan KE dengan alfa $=5 \%$. Hasil yang didapatkan adalah $p=0,030(p<0,05)$. Dengan demikian dapat disimpulkan bahwa terdapat perbedaan tingkat resistensi terhadap perubahan sasaran kinerja yang signifikan antara kelompok eksperimen dan kelompok kontrol.
Berdasarkan hasil ini dapat disimpulkan bahwa terdapat perbedaan skor resistensi terhadap perubahan sasaran kinerja pada kelompok eksperimen yang mengikuti kegiatan keterlibatan penyusunan KPI dibandingkan dengan kelompok kontrol management trainee Universitas $\mathrm{X}$ yang tidak mengikuti kegiatan.

Tabel 3. Perbandingan Mean Kelompok Eksperimen dan Kelompok Kontrol

\begin{tabular}{llll}
\hline No & Mean & $\begin{array}{l}\text { Kelompok } \\
\text { Eksperimen }\end{array}$ & $\begin{array}{l}\text { Kelompok } \\
\text { Kontrol }\end{array}$ \\
\hline 1 & Prates & 71,625 & 65,5 \\
2 & Pascates & 66,5 & 65,875 \\
3 & Gain score & 5,5 & 3,125 \\
\hline
\end{tabular}

Selain itu, diperoleh data gain score kelompok eksperimen dengan memper- oleh mean sebesar -5,125 dan skor mean untuk data gain score kelompok kontrol 
sebesar 0,375. Berdasarkan penjelasan di atas dapat disimpulkan bahwa terdapat perbedaan skor mean antara data gain score kelompok eksperimen dan kontrol sebesar 5,5. Berdasarkan data tersebut dapat dinyatakan bahwa Management trainee yang terlibat dalam penyusunan KPI memiliki skor resistensi terhadap perubahan sasaran kinerja yang lebih rendah dibandingkan dengan management trainee yang tidak terlibat dalam penyusunan $\mathrm{KPI}$.

Tujuan dari penelitian ini adalah untuk menguji efektivitas keterlibatan penyusunan Key Performance Indicator dalam menurunkan tingkat resistensi terhadap perubahan sasaran kinerja. Efektivitas suatu perlakuan dapat dilihat dari rata-rata nilai gain score pada kelompok eksperimen dan kelompok kontrol. Hal ini diungkapkan oleh Seniati dkk (2011) yang menyatakan bahwa untuk mengetahui seberapa efektif suatu perlakuan dapat dilihat dari rata-rata nilai selisih pada kedua kelompok yang ditunjukkan dengan mean gained score kelompok eksperimen yang lebih besar dari mean gained score kelompok kontrol. Berdasarkan perhitungan, diperoleh nilai mean gained score kelompok eksperimen sebesar 5,5 dan mean gained score kelompok kontrol sebesar 3,125, sehingga dapat dinyatakan bahwa mean gained score kelompok eksperimen lebih besar dari mean gained score kelompok kontrol.
Berdasarkan hal tersebut dapat disimpulkan bahwa keterlibatan penyusunan KPI terbukti efektif dalam menurunkan tingkat resistensi terhadap perubahan sasaran kinerja pada management trainee Universitas $X$.

\section{PEMBAHASAN}

Tujuan dari penelitian ini adalah untuk menguji efektivitas kegiatan keterlibatan penyusunan KPI dalam menurunkan tingkat resistensi terhadap perubahan sasaran kinerja pada management trainee Universitas $X$. Terdapat dua hipotesis dalam penelitian ini, pertama terdapat perbedaan skor resistensi terhadap perubahan sasaran kinerja antara management trainee yang terlibat dan yang tidak terlibat dalam penyusunan KPI. Management trainee yang terlibat dalam penyusunan $\mathrm{KPI}$ memiliki skor resistensi terhadap perubahan sasaran kinerja yang lebih rendah dibandingkan dengan management trainee yang tidak terlibat dalam penyusunan KPI. Kedua, keterlibatan dalam penyusunan KPI efektif dalam menurunkan tingkat resistensi terhadap perubahan sasaran kinerja pada managament trainee Universitas $\mathrm{X}$.

Berdasarkan hasil analisis dengan menggunakan uji independent sample $t$ test pada gain score kelompok eksperimen dan kelompok kontrol, maka diperoleh hasil bahwa hipotesis penelitian ini 
diterima. Dilihat dari hasil analisis tersebut dengan alfa $=5 \%$, maka diketahui bahwa nilai signifikansinya adalah sebesar 0,030 atau $p<0,05$, dengan demikian dapat dinyatakan bahwa terdapat perbedaan skor resistensi terhadap perubahan sasaran kinerja antara management trainee yang terlibat dan yang tidak terlibat dalam penyusunan $\mathrm{KPI}$.

Kemudian dari hasil perhitungan mean diperoleh data bahwa mean prates $<$ mean pascates. Artinya bahwa terdapat penurunan resistensi perubahan sasaran kinerja setelah management trainee terlibat dalam penyusunan $\mathrm{KPI}$, sehingga dapat disimpulkan bahwa management trainee yang terlibat dalam penyusunan KPI memiliki skor resistensi terhadap perubahan sasaran kinerja yang lebih rendah dibandingkan dengan management trainee yang tidak terlibat dalam penyusunan $\mathrm{KPI}$.

Selain itu, berdasarkan hasil analisis terhadap selisih mean gain score kelompok eksperimen dan kelompok kontrol, diperoleh hasil bahwa mean gain score kelompok eksperimen lebih besar dari dan kelompok kontrol, sehingga dapat dinyatakan bahwa keterlibatan penyusunan KPI terbukti efektif dalam menurunkan tingkat resistensi terhadap perubahan sasaran kinerja yaitu dengan.

Hal ini sejalan dengan pendapat Zulkarnain dan Hadiyani (2014) yang menyatakan bahwa keterlibatan mempe- ngaruhi kesiapan karyawan untuk berubah. Hasil penelitian Freddy dan Mbohwa (2013) juga menyatakan bahwa kurangnya keterlibatan karyawan berdampak pada resistensi terhadap perubahan.

Selain itu, Agocs (1997) mengatakan salah satu faktor penyebab individu resisten terhadap perubahan adalah adanya kekhawatiran akan ketidaktahuan informasi. Pelibatan karyawan dalam proses penyusunan KPI merupakan salah satu cara pemberian informasi terkait dengan sasaran kinerja. Pelibatan karyawan ini diharapkan mampu mengurangi tingkat resistensi karyawan terhadap sasaran kinerja.

Hal ini selaras dengan hasil penelitian yang dilakukan oleh Khattak dkk (2012) bahwa keterlibatan dapat meningkatkan komitmen karyawan. Hasil penelitian Zulkarnain dan Hadiyani (2014) juga menyatakan bahwa komitmen dan keterlibatan karyawan berkontribusi terhadap kesiapan karyawan untuk berubah, sehingga pelibatan management trainee dalam menyususun KPI menjadi penting. Keterlibatan management trainee dalam menyusun KPI harapannya dapat menurunkan tingkat resistensi terhadap perubahan pada sasaran kinerja.

Permasalahan resistensi terhadap perubahan sasaran kinerja merupakan permasalahan yang terkait dengan aspek afeksi, sehingga melibatkan karyawan dalam menentukan target capaian kinerja 
menjadi penting. Hal ini sejalan dengan pendapat Shuck dkk (2011) bahwa keterlibatan merupakan proses kognitif individu secara emosional dan perilaku yang diarahkan menuju hasil yang diinginkan oleh organisasi.

Permasalahan terkait dengan aspek afeksi akan lebih efektif diatasi dengan hal yang dapat menyasar aspek afeksi. Keterlibatan sangat mengedepankan aspek afeksi. Hal ini sejalan dengan hasil penelitian Palmer (2006) yang menyatakan bahwa aspek emosi penting dalam mengkomunikasikan perubahan. Aspek emosi menjadi aspek yang penting dalam mengkomunikasikan perubahan. Palmer menyatakan bahwa aspek emosi dapat menjadi alat yang sangat penting untuk memunculkan keinginan, komitmen, dan usaha karyawan untuk melakukan suatu perubahan. Urgensi dapat dikomunikasikan lewat appeal emosional, visi dapat ditanamkan juga melalui appeal emosional, dan dengan appeal emosional perubahan yang hebat juga dapat dilakukan. Membawa karyawan pada emosi positif dapat memberikan ketertarikan pada karyawan terhadap perubahan (Palmer, 2006).

Berdasarkan data evaluasi kegiatan keterlibatan dapat dinyatakan bahwa peserta memiliki reaksi yang positif terhadap kegiatan, terutama terkait dengan trainer dan materi kegiatan. Reaksi yang baik dari peserta sangat berpengaruh terhadap baiknya peserta dalam menyerap informasi. Hal ini dapat dibuktikan dari skor evaluasi pengatahuan setelah kegiatan lebih tinggi dari skor evaluasi kegiatan sebelum kegiatan. Artinya bahwa pengetahuan peserta terkait dengan materi meningkat.

Pemahaman yang baik akan materi yang disampaikan dalam kegiatan berpengaruh pada seberapa baik sikap yang dimunculkan peserta terhadap kegiatan. Hal ini dibuktikan dengan terbuktinya hipotesis bahwa dengan kegiatan keterlibatan penyusunan KPI, tingkat resistensi terhadap perubahan sasaran kinerja menjadi menurun.

\section{SIMPULAN DAN SARAN}

\section{Simpulan}

Berdasarkan hasil penelitian yang telah dilakukan, dapat ditarik kesimpulan bahwa berdasarkan uji independent sample $t$ test pada gain score hipotesis penelitian diterima. Hal tersebut berarti bahwa terdapat perbedaan skor resistensi terhadap perubahan sasaran kinerja antara management trainee yang terlibat dan yang tidak terlibat dalam penyusunan KPI. Management trainee yang terlibat dalam penyusunan KPI memiliki skor resistensi terhadap perubahan sasaran kinerja yang lebih rendah dibandingkan dengan management trainee yang tidak terlibat dalam 
penyusunan KPI. Selain itu, keterlibatan penysunan KPI terbukti efektif dalam menurunkan tingkat resistensi terhadap perubahan sasaran kinerja pada management trainee Universitas $X$.

Selain itu, dapat juga disimpulkan bahwa terdapat korelasi signifikan antara keterlibatan penyusunan KPI dengan penurunan tingkat resistensi terhadap perubahan sasaran kinerja dengan nilai korelasi sebesar 0,837 dan signifikansi 0,000 . Berdasarkan data tersebut dapat dinyatakan bahwa penurunan tingkat resistensi terhadap perubahan sasaran kinerja benar-benar disebabkan oleh keikutsertaan peserta dalam kegiatan keterlibatan penyusunan KPI.

\section{Saran}

Terdapat saran yang diberikan oleh peneliti. Pihak organisasi diharapkan untuk melibatkan karyawan dalam kegiatan organsiasi khususnya dalam setiap langkah penyusunan KPI. Organisasi harus memastikan bahwa setiap karyawan terlibat dalam semua proses penyusunan KPI. Harapannya bahwa keterlibatan dalam setiap langkah penyusunan KPI dapat berpengaruh terhadap menurunnya tingkat resistensi terhadap perubahan. Pihak karyawan sebaiknya ikut terlibat dalam kegiatan organsiasi khususnya dalam penyusunan KPI untuk menghindari resistensi terhadap perubahan sasaran kinerja. Hal ini dikarenakan dengan meningkatnya keterlibatan, maka karyawan memiliki tanggungjawab untuk mencapai sasarn kinerja yang telah ditentukan sebelumnya. Karyawan harus sepenuhnya terlibat dalam setiap langkah penyusunan $\mathrm{KPI}$.

\section{DAFTAR PUSTAKA}

Agocs, C. (1997). Institutionalized resistance to organizational change: Denial, inaction, and repression. Journal of Business Ethics. 16.9. 917-931

Armstrong, M. (2003). Mengelola karyawan: Buku wajib bagi manajer lini. Diterjemahkan oleh Ramelan dan Dwi Prabaningtyas. Jakarta: PT Gramedia

Azwar. S. (2010). Reliabilitas dan validitas. Yogyakarta: Pustaka Pelajar

Boohene, R. \& Williams, A.P. (2012). Resistance to organizational change: A case study of Oti Yeboah Complex Limited.

Bovey, W. H \& Hede, A. (2001). Resitance to organizational change: the role of cognitive and affective processes. Leadership and Organization Development Journal. 22. (8). 372-382

Cook, T. D., \& Campbell, T. D. (1979). Quasi-experimentation: Design \& analysis issues for field settings. Boston: Houghton Mifflin 
Cristensen, L. B. (2001). Experimental methodology. 4th edition. USA: Allyn and Bacon, Inc

Cummings, T. G \& Worley, C, G. (2005). Organization development and change. 9 edition. Canada: Cengange Learning

Erwin, D, G. \& Garman, A, N. (2010). Resistance to organizational change: Linking research and practice. Journal of Leadership \& Organizational Development. 31. (1). 39-56.

Freddy, C \& Mbohawa, C. (2013). Ways to overcome employee resistance in change initiatives. International conferenceon law, entrepreneurship, and industrial engineering.

Haynes, C. (2007). Experiential learning: learning by doing: 5 step experiential learning cycle definitions. Diakses dari kiolo002F tanggal 15 April 2017.

Kanungo. R. N. (2012). Measurement of job and work involvement. Journal of Applied Psychology.(76). 341349

Khattak, M., A; Nadeem, I; Urooj, S, F; \& Bashir, F. (2012). Employee involvement and participation at work: a case study of OTCL after privatization. International journal of academic research and business and social csience. 2. (6)
Kreitner, R \& Kinicki, A. (2001). Organizational behavior: perilaku organisasi. Jakarta: Salemba empat

Latipun. (2006). Psikologi eksperimen. Malang: UMM Press

Luthans, F. (2005). Perilaku organisasi edisi 10. Andi: Yogyakarta

Palmer, I., Dunford, R. \& Akin, G. (2006). Managing organizational change: $A$ multiple perspectives approach. 2nd edition.

Moeheriono. (2012). Perencanaan, aplikasi, dan pengembangan indikator kinerja utama (IKU) bisnis dan publik. Cetakan Kedua. Bandung: PT Remaja Rosdakarya

Oebaidillah, S. (2017). Hadapi perubahan, perguruan tinggi harus siap berkompetisi. diakses dari http://www. mediaindonesia.com/news/read/91 133/hadapi-perubahan-perguruantinggi-harus-siap-berkompetisi/ 2017-02-07tanggal 16 Maret 2017.

Oreg, S. (2003). Resistensi terhadap perubahan: Developing an individual differences measure. Journal of Applied Psychology, 88(4), 680693.

Palmer, I; Dunforn, R; \& Akin, G. (2006). Managing organizational change. Singapore: Mc Graw Hill.

Parmenter. D. (2007). Key performance indicator: Developing, implementing, and using winning KPI. New Jersey:John Wiley \& Sons, Inc. 
Rislisa, H, F. \& Himam, F. (2015). Pengaruh keterlibatan pelatihan key performance indicator (KPI) terhadap komitmen sasaran kerja karyawan di PT. XYZ, Yogyakarta. Jurnal Psikologi Undip. 14. (2).

Rivai, V \& Sagala, E. J. (2013). Manajemen sumber daya manusia untuk perusahaan. Cetakan kelima. Depok: PT Rajagrafindo Persada.

Robbins. S. P. (2001). Perilaku organisasi, konsep, kontroversi, aplikasi. Jakarta: Prenhallindo.

Sembiring, J. (2009). Manajemen perubahan: Rangkuman teori dan aplikasi. Jurnal Manajemen Indonesia. 9. (1).

Shadish, W. R., Cook, T.D. \& Campbell, D. T., (2002). Experimental and quasy-experimental designs for generalized causal inference. Boston: Houghton Mifflin Company.

Shuck, M. B; Rocco, T. S. \& Albornoz, C. E. (2011). Employee engagement from the employee perspective: Implications for HRD. Journal of European Industrial Training. 35. (4). 300-325.

Soemohadiwidjojo, A. T. (2015). Panduan praktis menyusun KPI. Jakarta: raih Asa Sukses

Sugiyono. (2012). Metode penelitian kuantitatif, kualitatif dan $R \& D$. Bandung: Alfabeta

Yilmaz, D \& Kilicoglu, G. (2013). Resistensi terhadap perubahan and ways of reducing resistance in educational organizations. European journal of research on education. 1 (1), 14-21.

Zatzick, C. D. (2001). Self affirmation analysis of employee resistance to organizational change. Dessertation.

Zulkarnain \& Hadiyani, S. (2014). Peranan komitmen organisasi dan employee engagement terhadap kesiapan karyawan untuk berubah. Jurnal psikologi. 41(1), 17-33. 


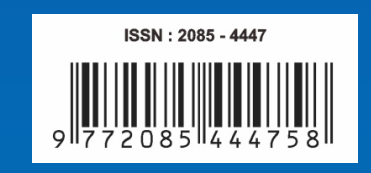

